\title{
BOWHEAD WHALES IN THE BEAUFORT SEA
}

\author{
by ERNIE KUYT*
}

During aerial surveys for sea ducks n May and June of 1972 and 1973, pur flights followed the major ice leads $n$ the southern part of Beaufort Sea. This provided an opportunity to oberve the large mammals occurring long the leads. We saw Polar Bear Thalarcticos maritimus), Ringed Seal Phoca hispida), Beluga (Delphinaperus leucas) and Bowhead Whale Balaena mysticetus). Two or three owheads were seen on June 8, 1972, n deep water between Baillie Island nd Banks Island (approx. $71^{\circ} \mathrm{N}$., $27^{\circ} \mathrm{W}$.). Between three and five rowheads together were sighted on feptember 13, 1973, in ice-free waters bout 50 meters deep (hydrographic harts, Canadian Hydrographic Serice, Ottawa) halfway between Herchel Island and Roland Bay (approx. $9^{\circ} 30^{\prime} \mathrm{N} ., 139^{\circ} \mathrm{W}$. .).

Inhabitants of Herschel Island told he earlier on September 13 that everal bowheads had been in the area, ne of which had torn up a seal net in auline Cove $\left(69^{\circ} 35^{\prime} \mathrm{N} ., 139^{\circ} \mathrm{W}\right.$.). hese large-mesh nets had yielded onsiderable numbers of Ringed Seal, everal Beluga, one or two Harbour eals (Phoca vitulina) and a young bull Valrus (Obobenus rosmarus). The Herchel Island hunters indicated they tended to hunt bowhead and for that urpose some Beluga hunting equiphent had been modified.

During an aerial waterfowl survey n August 27, 1973, I spotted a straned Bowhead Whale about 22 miles

Box 508,

ort Smith, N.W.T.

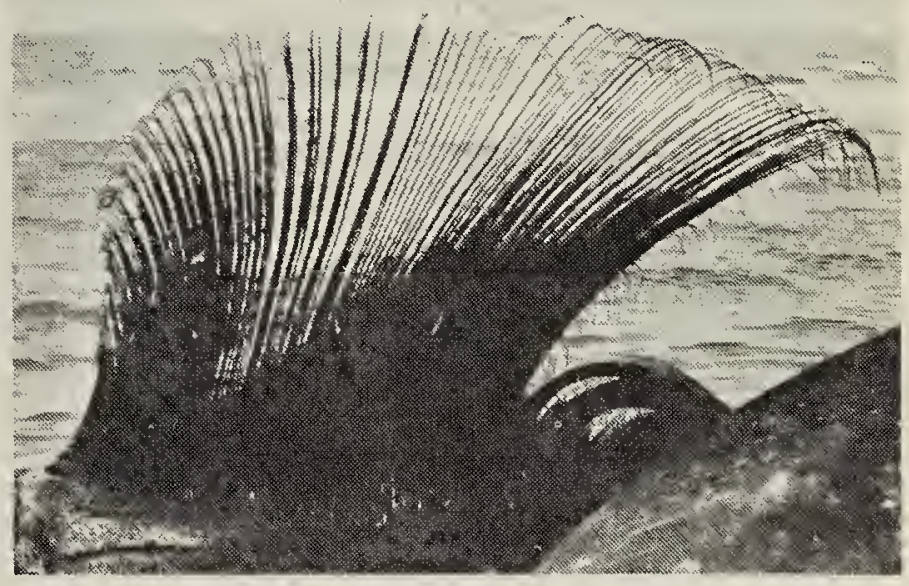

Close-up of baleen, Bowhead Whale. Aug. $27 / 73$.

Ernie Kuyt

northeast of Tuktoyaktuk. Upon closer examination, we found the 54-foot long whale to be resting on its right side. The animal was blackish brown except for a yellow-gray area near the tip of the mandible and near the tail, including the ventral surface of the flukes. I estimated about 200 plates of baleen on each side of the narrow upper jaw, with about one-third of the baleen plates partly hidden by the mandible. The most anterior plates were only a few inches long with a gradual increase in length of the baleen to 7 feet at about two-thirds of the way toward the angle of the jaw. W. Gillies Ross, examining log book records of whaling voyages, reported mature whales yielding baleen of over 10 feet, whereas a "small" whale taken had 5-foot long baleen."

The dead whale had several small wounds: the largest one, about 4 inches across, was located 2 feet anterior to the genital opening, and three smaller wounds were observed in the axillary 




Rear view of Bowhead Whale. Aug. 27/73.

Ernie K

region of the left flipper. The origin of the wounds could not be ascertained but birds had been feeding at these sites. About 100 Glaucous Gulls were concentrated at the bowhead's carcass but no mammal tracks were observed. indicative perhaps of a recent stranding of the whale.

E. D. Mitchell gives details on the observation and status of whales but it appears that little is known about the numerical status of the bowhead in the Canadian Arctic.'

Other than the above-mentioned whale hunting at Herschel Island. I know of no other bowhead hunt taking place in the Canadian West Arctic. Alaskan Eskimos, usi shoulder-guns and other weapons, s hunt the bowhead (J. Bockstoce, po comm.) but the effect on whale sto of the hunting, including the high $r$ of losses due to wounding is known.'

'MITCHELL. E. D. 1973. The status of the w whales. 1973. Nature Canada 2(4):9-25.

"ROSS. W. G. 1974. Distribution. migration depletion of bowhead whales in Hudson 1860 to 1915. Arctic and Alpine Rese: $6(1): 85-98$. 